\author{
BULETINUL INSTITUTULUI POLITEHNIC DIN IAŞI \\ Publicat de \\ Universitatea Tehnică „Gheorghe Asachi” din Iaşi \\ Volumul 67(71), Numărul 1, 2021 \\ Secţia \\ CONSTRUCTII. ARHITECTURĂ \\ DOI: $10.2478 /$ bipca-2021-0003

\section{sciendo}

\title{
SEISMIC RESPONSE OF THREE-LOBED SHAPE
}

BY

\author{
MIHAI IRIMIA ${ }^{1 *}$ \\ Technical University of Civil Engineering, Bucharest
}

Received: December 05, 2020

Accepted for publication: January 18, 2021

Abstract. The paper deals with the three-lobed churches, the most representative creations of the ecclesiastic and monumental architecture preserved in the Carpathian-Danubian-Pontic area. Beginning with the fourteenth century, in Moldavia and Wallachia, the old wooden churches, often threatened by the fire, were replaced with stone or brick masonry ones. Unfortunately, strong and enduring earthquakes occur in this area. The stone and brick masonry, with clay or lime mortars, used for three-lobed churches, including their foundations and steeples, were often severely damaged by earthquakes. According to a legend, in the case of the Church of Arges Monastery, usually the damages occurred during the nights. To save the church, by the virtue of an old myth, the Manole Master has immolated his wife into one of the pronaos walls. By that occasion, the whole pronaos was enlarged and the church was no longer damaged. The later research has shown that by reshaping the pronaos, the relative positions of the weight center and the stiffness center have been reversed. Since then, that beautiful church, during its long service of 503 years, was never damaged again by earthquakes. The same happy fate has been experienced by the subsequent three-lobed churches which adopted the same enlarged pronaos.

Keywords: Earthquake, immolation, jerk, resilience, shaping.

${ }^{*}$ Corresponding author; e-mail: irimia_mihai_cristian@yahoo.com (C) 2021 Mihai Irimia

This is an open access article licensed under the Creative Commons Attribution-NonCommercialNoDerivatives 4.0 International License (CC BY-NC-ND 4.0). 


\section{Introduction}

The oldest monumental buildings preserved in the Carpathian-DanubianPontic space on the Romanian territory are the three-lobed churches. The region is well known for early Christianity. For centuries they have been the most representative creations of church and monumental architecture. Erected from stone or brick masonry and lime mortars, the Balkan-Byzantine style of churches have always been the proof of technical knowledge and artistic refinement achieved on the Romanian territories over the centuries.

These churches have always represented the typical Orthodox style. Romanians are the only Latin people of Orthodox religion, while the other Latin peoples or those with Latin origins are Catholic. Among the first three-lobed churches is the Church of the Holy Trinity of the Siret in Moldavia, built-in 1376, and Cozia Monastery, built-in 1386. Both are well preserved and are still functional. (Fig. 1)

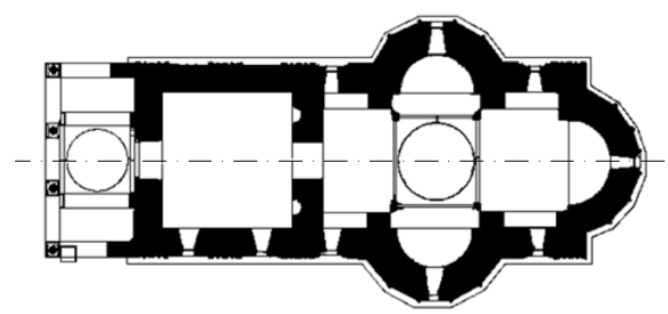

Fig. 1 - The shaping Cozia Monastery

Unfortunately, strong tectonic earthquakes frequently occur in this area. According to a study conducted by Stefanescu on earthquakes in Romania between 455 and 1846, an average of 12 earthquakes were felt in our country per century, and in the first half of the last century, two out of three earthquakes during occurred night (Stefanescu, 1901).

The two great earthquakes of the twentieth century, that of November $10^{\text {th }}, 1940$, and that of March $4^{\text {th }}, 1977$, occurred also durring night. The earthquakes produced in the Vrancea seismic area are characterized byhigh magnitudes, all over 7 on Richter scale, their focuses are deep, ofen over 150 $\mathrm{km}$, and their duratios are long, over 50 seconds.

The construction of Saint Peter's Basilica in Rome begun with Pope Julius in 1506 and was complete, in 1615. It was designed as a Latin cross with three naves, with a dome resting at the intersection of the naves, being positioned above the apple altar. In 1546 Michelangelo was hired as chief architect and he designed St. Peter's Domme. Coincidentally, the construction of St. Peter's Basilica and the Arges Church in Wallachia began in the same periods. The Arges Church has the shape of a Greek cross with three lobes. Both churches are 
masterpieces of art and architecture. Before the completion of the construction, both had technical problems: gravity for St. Peter's and mysterious forces that occured according to the legend, during the nights only, in the case of the Arges Church. After an appropriate reshaping the Churche behave safely during a service of five century.

Similar interventions were made on the three-lobed shaped in order to improve their seismic behavior, but they did not have the same result like in the case of the Arges Church, e.g.: Curtea Veche Church, Mihai Voda Church, Snagov Monastery Church, Antim Monastery Church.

In the case of the Antim Monastery, due to the jerk effect, the towers collapsed twice, in 1738 and 1940 (Sofronie and Virsta, 2006).

\section{The origin of the three-lobed churches}

The typical plan of the Orthodox churches preserved on the Romanian territory is based on the Byzantine scheme of the Greek churches, namely the inscribed right cross, with a dome supported on columns. However, this style was adapted to the regional traditions of architecture. It can be seen that Romanian architecture had a major influence on the church plan. For example, the dome has been replaced by a Pantokrator steeple and no longer rests directly on pillars or columns, but transmits the efforts through pendantives to four semicircular arches. In this way was created inside the nave, which remained free for religious service. The nave is extended further by two side apses and close by the apse of the holly altar. The other part of the nave is continued by a rectangular or square pronaos, also called a pronaos, sometimes extended with an exonarthex or porch (Ionescu, 1982).

Such a shape in the plane of three-lobed churches has a vertical longitudinal plane of symmetry. In this respect, the body of the church, together with the steeple is very carefully balanced in the gravitational field. In the first phase, these churches had a single steeple, that of Pantokrator. Later, two, three or even four steeple were added to decorate these monuments. Sometimes one of the towers was used as a bell tower, for fire observation. (Ionescu, 1982)

The slenderness of steeples was used as an aesthetic criterion.

\section{Seismic damage}

In general, three-lobed churches were built without a basement, their foundations usually having a depth between $30-90 \mathrm{~cm}$. A fault foundation allows the degradation of the walls of the apses and the transverse arches. This is the particular case of churches rebuilt in a new style of masonry on the existing foundations of wood or stone churches destroyed by earthquakes. However, there were churches with a three-lobed plan that did not suffer from damages caused by earthquakes for centuries. It was observed that in certain small areas, churches 
built of brick built in the same period with the same size and comparable foundations behaved differently under the action of earthquakes. Some of them suffered serious damage, while others did not suffer any damages. The explanation for different behavior is the different shaping of the churches.

Regarding the damage caused by earthquakes, the steeples are first mentioned. Usually, the steeples were built of masonry and yielded more easily to shear forces than those of Moldovian churches, where the steeple towers were built of wood. Consequently, in Bucharest, one of three churches has a false steeple, made of wood.

The apses of the nave and the altar were also severely damaged by the earthquakes by shearing the curved walls. Typical damage consists of vertical cracks in curved or polygonal walls and cracks at $45^{\circ}$ at the corners of window openings. The two types of cracks developed in the walls of the pronaos, when they were not supported at their tops. The semicircular arches were built to reduce the openings and to support the dome and the steeple. Therefore, it is assumed that certain anti-seismic forms were more or less consciously adopted. However, no written rules or documents have been kept to date. They remained professional secrets. Instead, there is an old legend about Wallachian church builders (Beles, 1937; Sofronie, 2017; Timoshenko, 1930, 1953).

\section{Master Manole's Legend.}

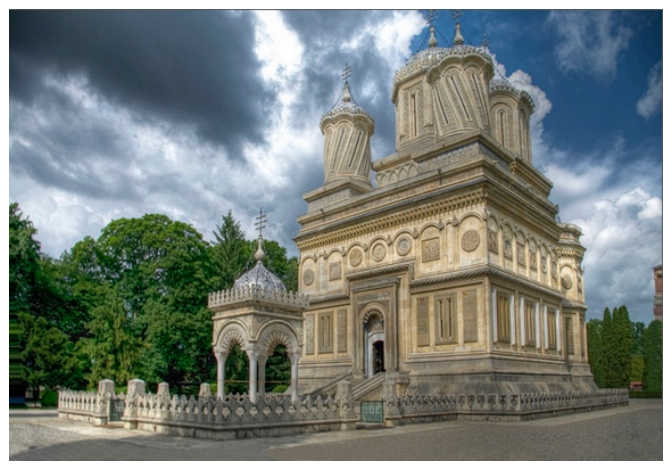

Fig. 2 - View of Arges Monastery Church

One of the most representative three-lobed churches in Romania is that of Arges Church. It was built up in six years, between 1512 and 1518, under the reign of Prince Neagoe Basarab. Later, around that Church, a monastery was raised. Due to its remarkable beauty and fame, many other churches have adapted a similar shape. Today it is a Bishop Church and quoted as a patrimonial monument under UNESCO protection.Long ago, the fame of Arges Church has been spread through a famous legend (Fig. 2). 
According to the legend, Negru Voda entrusts a team of masons with the mission to build an exceptional church somewhere down on Arges River. They start working, only that everything that was built during the day, it was collapsing during the night. Only after the immolation of Anna, Master Manole's wife, the church could be finished. In the end, the masons were also sacrificed. Their work, on the other hand, has lasted for centuries.

In 1943, Mircea Eliade published in Bucharest a book entitled Comments on the Legend of Master Manole, regarded from the perspective of the History of Religions (Eliade, 1943). Mircea Eliade interpreted the myth of immolation, as an act of symbolic life of construction of great importance for society. He recognized in the ritual of construction sacrifice a reply to the primordial act of creation, attributing to its cosmogonic origins. At the same time, Mircea Eliade rediscovers the philosophy of the paradoxical unity between life and death.

After analyzing the different meanings of the legend of Master Manole, Mircea Eliade states three open questions: 1 . What is the true meaning of the myth of immolation? 2. For what reasons did the Romanian people create, cultivate, and preserves this mythical scenario? 3. How is the total adherence of the people to the ritual of construction sacrifice explained?

Looking at the Legend of Master Manole from an engineering perspective, it is easy to conclude that of all the possible actions, which were able to cause the repeated collapse of the masonry walls, there could be nothing else but earthquakes. Indeed, tectonic earthquakes, typical of the Carpatho-Danubian area, occur frequently during the nights, are recurrent, and show special aggression against curved walls and arches of masonry vaults. The old Metropolitan Church, mentioned in the Legend, could also be destroyed by the seismic action. As a consequence of the immolation, this consists in enlarging the pronaos and thus ensuring seismic protection. It was an inspired solution because for 503 years, from 1518 to 2021, the church behaved perfectly under earthquakes actions. The plan with three lobes, with an enlarged pronaos like the church of the Arges Church, was adopted in the case of other Wallachian Churches. Indeed, all rigorously preserved the shape of this model behaved excellently in the earthquake, although some of them, namely those in Bucharest, were with a higher degree of seismicity. Thus, the anti-seismic qualities of the shape has been certainly proven.

The legend of Master Manole presents impressive content through its actuality. The following questions were answered: 1 . The true meaning of the myth of immolation is the struggle of the people against the destructive actions of the earthquake. This struggle can only be won by a supreme sacrifice, a price that the people understood was necessary to pay for safety and peace of life; 2 . The content of the myth of immolation is secular, not religious, created because its time is the only universal means of communication, accessible to all. It has been cultivated to keep the professional secret unaltered, thus eliminating the risk of damage or catastrophe. The myth has been preserved over the time, as the risk 
of an earthquake is permanent and appropriate seismic measures must be taken for any other construction; 3 . The total adherence of the people to the ritual of construction sacrifice can also be explained by the joy of liberation from the obsession that seemed imminent and uncontrollable. The people receive the security of a free and dignified spiritual life, so the sacrifice is accepted serenely and consciously by all participants in this ritual. It is thus stated that the myth of immolation expresses the vocation as a builder of our people, the tenacity and power of the Romanian soul, as well inventiveness and spiritual vigor. In Fig. 3 are presented some churches with pronaos enlarged according to the Legend ( Paun, 2003; Sofronie, 1982, 1983).

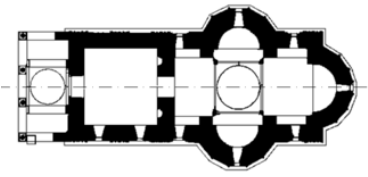

1386 - Cozia Monastery

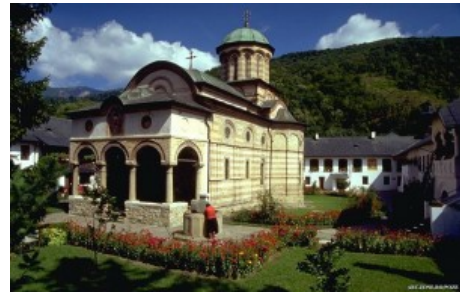

View of Cozia Monastery

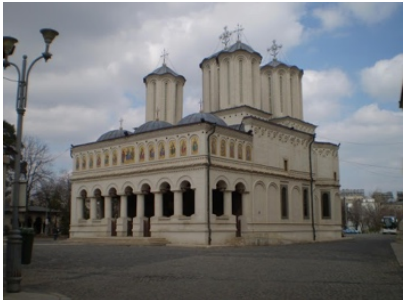

View of Patriarchal Cathedral Bucharest
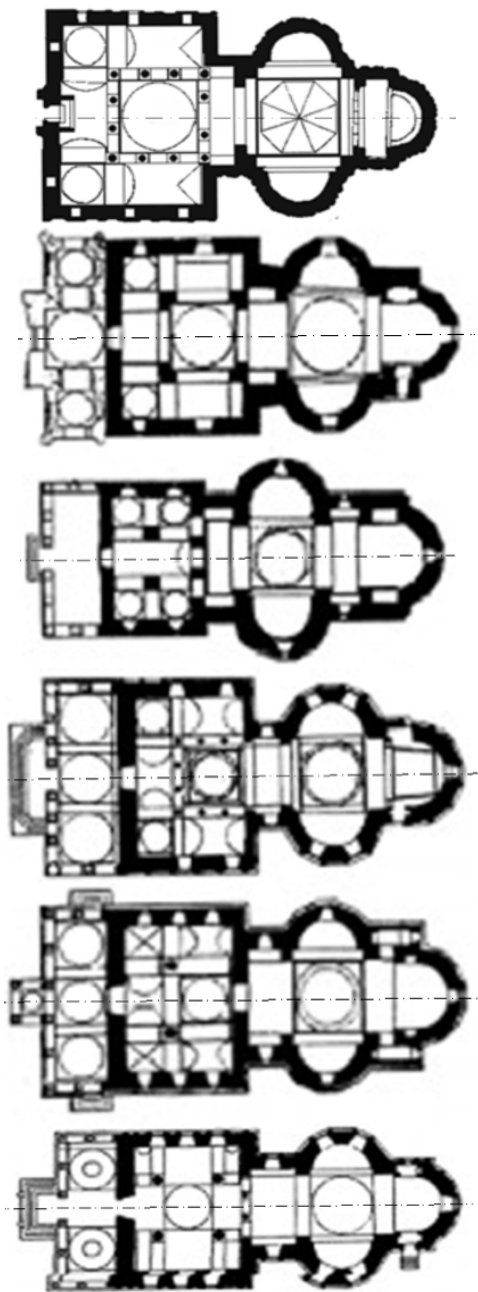

Vacaresti

Church
1722

1512

Arges

Monastery

Church

1615

Radu Voda

Church,

Bucharest

1636

Caldarusani

Church

1655

Patriarchal

Cathedral

Bucharest

1692

Hurez

Church

Fig. 3 - Examples of churches with an enlarged pronaos 


\section{Numerical Modeling}

\subsection{The influence of the remodeling of the three-lobed shape}

Numerical modeling demonstrates the step taken on the shaping of the structure by Master Manole's in the conception of the plan of the Arges Monastery Church, compared to the three-lobed type of the Cozia Monastery Church, from 1386, by enlarging the pronaos, as illustrated in the Fig. 4. Starting from the existing structure, referred to as real model, it will pass to a three-lobed reference model, according to the Cozia Monastery Church. The modeling was done in the Etabs program, using "shell" elements. The subject was developed in the author's doctoral thesis, where it was checked the conformation of several churches such as Curtea Veche Church, Mihai Voda Church, Snagov Monastery Church, Antim Monastery Church (Sofronie, 2019).

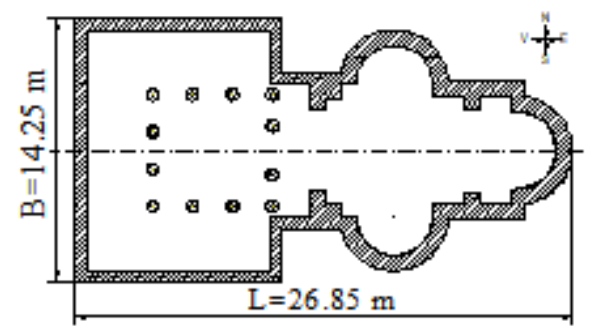

a) Real model

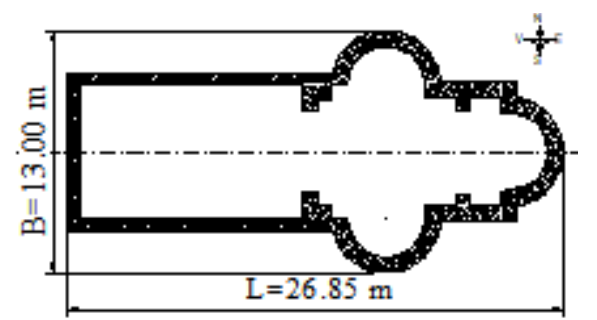

b) Three-lobed reference plan

Fig. 4 - The plan of Arges Monastery Church

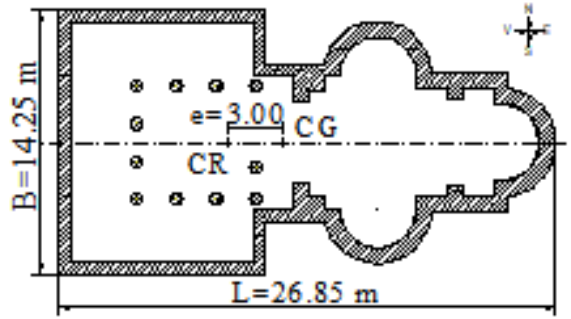

a) Real model

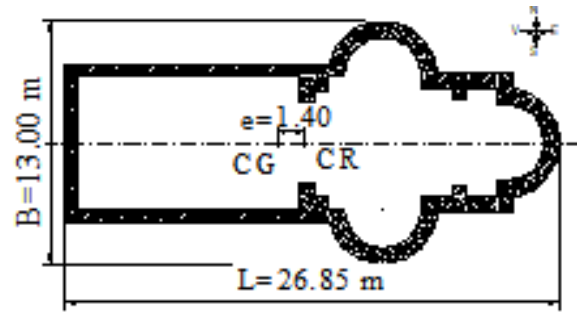

b) Three-lobed reference plan

Fig. 5-Distribution of centers of mass and rigidity for Arges Monastery Church

Table 1

The eccentricity between the center of mass and rigidity

\begin{tabular}{|c|c|}
\hline Real model & Three-lobed reference model \\
\hline Eccentricity & Eccentricity \\
\hline $\mathrm{e}=3.00 \mathrm{~m}$ & $\mathrm{e}=1.40 \mathrm{~m}$ \\
\hline
\end{tabular}


Real model

Mode $1, \mathrm{~T}=0.321 \mathrm{~s}$

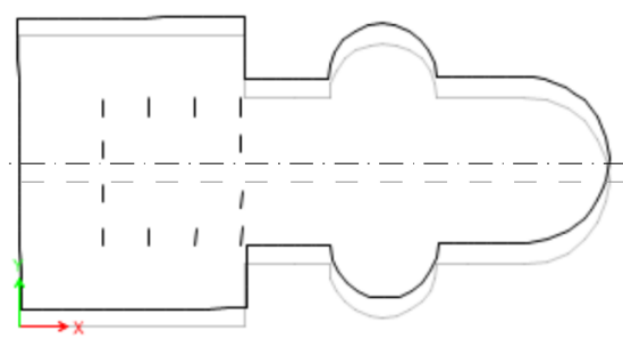

Mode 2, $\mathrm{T}=0.296 \mathrm{~s}$

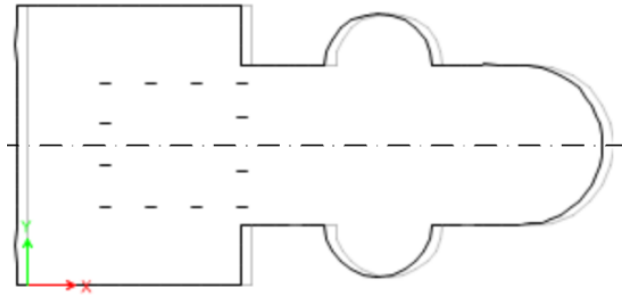

Mode 3, $\mathrm{T}=0.272 \mathrm{~s}$

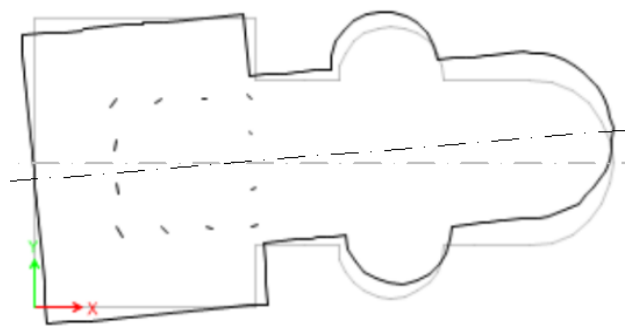

Three-lobed reference model Mode $1, \mathrm{~T}=0.350 \mathrm{~s}$

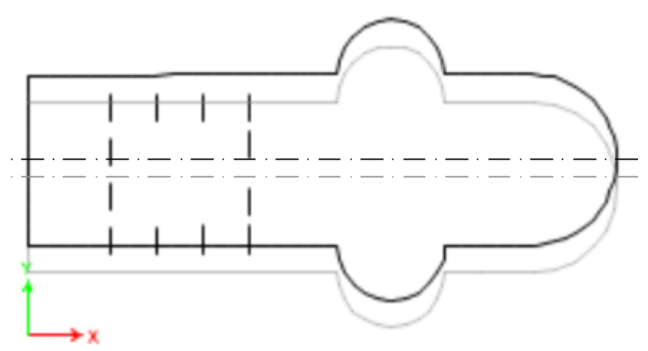

Mode 2, $\mathrm{T}=0.295 \mathrm{~s}$

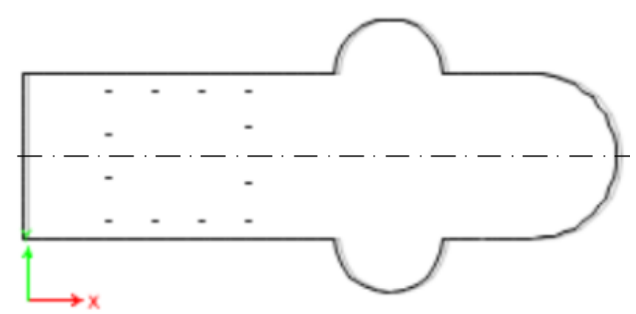

Mode 3, $\mathrm{T}=0.264 \mathrm{~s}$

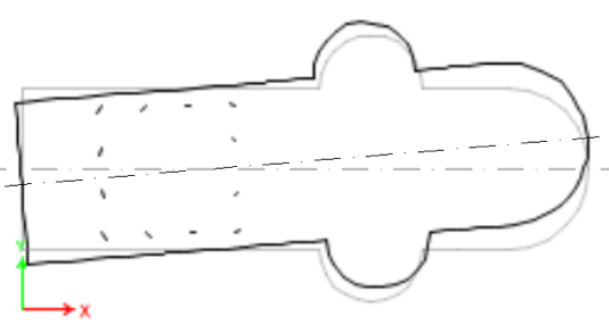

Fig. 6 - The three modes of oscillation for Arges Monastery Church

Table 2

The value of the seismic resilience for the real and the three-lobed reference modelArges Monastery Church

\begin{tabular}{|c|c|c|}
\hline Real Model & Three-lobed treference model & Difference \\
\hline $\begin{array}{c}\text { Seismic resilience - } \\
\text { longitudinal } \\
\text { direction }=70 \%\end{array}$ & $\begin{array}{c}\text { Seismic resilience - } \\
\text { longitudinal direction }=50 \%\end{array}$ & $\Delta_{\text {longitudinal }}=20 \%$ \\
\hline $\begin{array}{c}\text { Seismic resilience - } \\
\text { transversal direction }=35 \%\end{array}$ & $\begin{array}{c}\text { Seismic resilience - } \\
\text { transversal direction }=25 \%\end{array}$ & $\Delta_{\text {transversal }}=10 \%$ \\
\hline
\end{tabular}




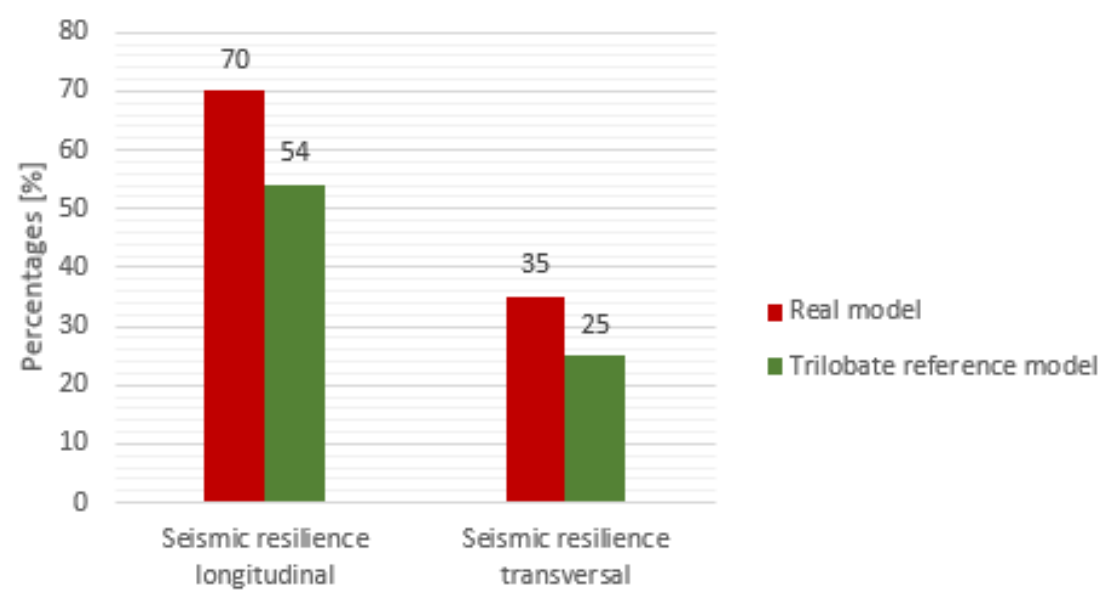

Fig. 7 - Seismic resilience comparison for the real model and the reference three-lobed model - Arges Monastery Church

Tabel 3

The value of the seismic risk for the real and the three-lobed reference model-Arges

\begin{tabular}{|c|c|c|}
\multicolumn{4}{|c}{ Monastery Church } \\
\hline Real model & Three-lobed reference model & Difference \\
\hline $\begin{array}{c}\text { Seismic risk - longitudinal } \\
\text { direction }=30 \%\end{array}$ & $\begin{array}{c}\text { Seismic risk - longitudinal } \\
\text { direction }=50 \%\end{array}$ & $\Delta_{\text {longitudinal }}=20 \%$ \\
\hline $\begin{array}{c}\text { Seismic risk - transversal } \\
\text { direction }=65 \%\end{array}$ & $\begin{array}{c}\text { Seismic risk - transversal } \\
\text { direction }=75 \%\end{array}$ & $\Delta_{\text {transversal }}=10 \%$ \\
\hline
\end{tabular}

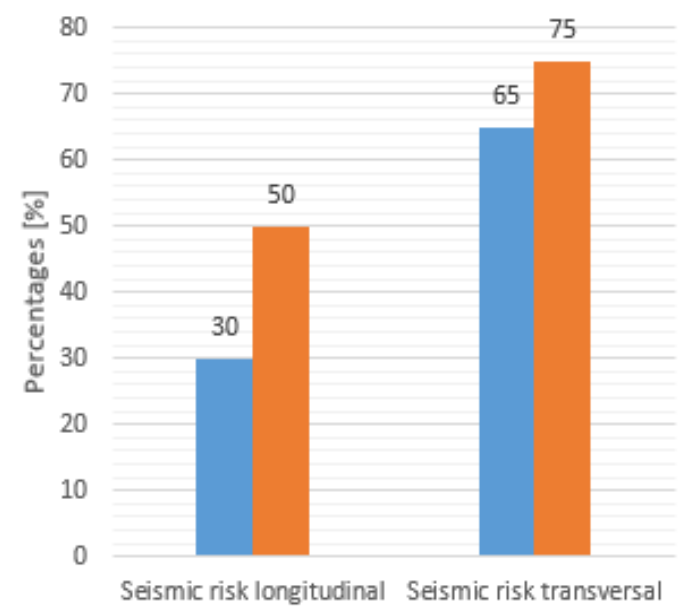

Real model

- Trilobate reference model

Fig. 8 - Seismic risk comparison for the real model and the reference three-lobed model - Arges Monastery Church 
Tabel 4

Comparative table between oscillation periods for the real model-reference three-lobed model - Arges Monastery Church

\begin{tabular}{|c|c|c|c|c|c|c|}
\hline \multicolumn{2}{|c|}{ Real model } & \multicolumn{2}{c|}{ Reference three-lobed model } & \multicolumn{3}{c|}{ Difference } \\
\hline Mode & Period (s) & Mode & Period (s) & Mode & Period (s) & Percentages (\%) \\
\hline 1 & $0.321 \mathrm{~s}$ & 1 & $0.350 \mathrm{~s}$ & 1 & 0.029 & $9.03 \%$ \\
\hline 2 & $0.296 \mathrm{~s}$ & 2 & $0.295 \mathrm{~s}$ & 2 & -0.001 & $-0.34 \%$ \\
\hline 3 & $0.272 \mathrm{~s}$ & 3 & $0.264 \mathrm{~s}$ & 3 & -0.008 & $-2.94 \%$ \\
\hline
\end{tabular}

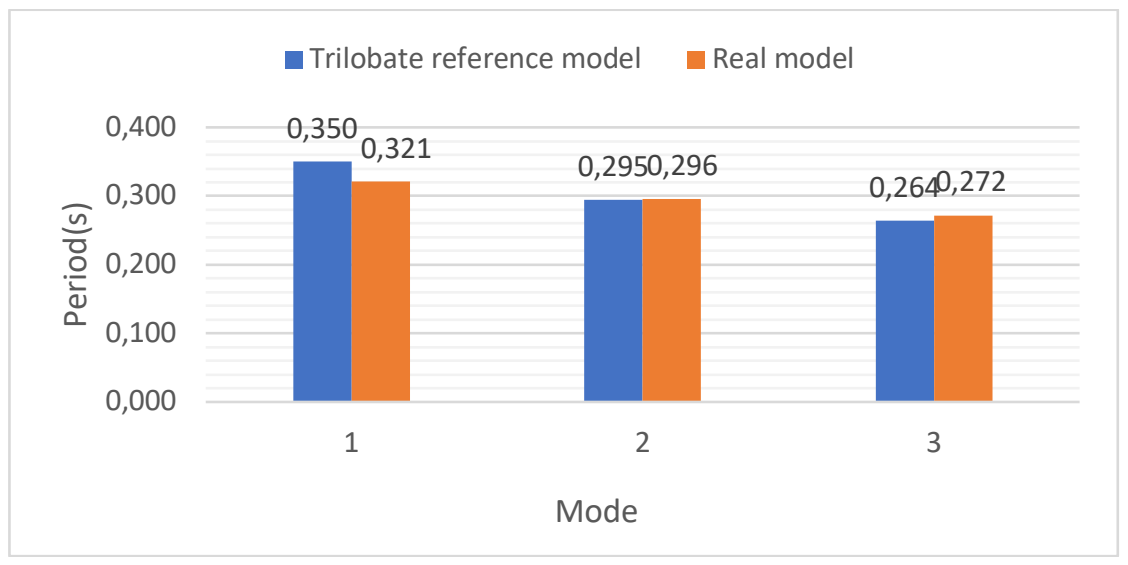

Fig. 9 - Graph of oscillation periods - Real model, reference three-lobed model - Arges Monastery Church

Studying the above graphs, it can be observed that by shaping the Arges Church to the one from Cozia, the position of the center of rotation CR changes, passing, on the axis of symmetry of the structure, the other side of the center of gravity CG. In this case, the eccentricity increased by around $10 \%$. At the same time, the distance from the center of rigidity $\mathrm{CR}$ to the walls of the apses has increased substantially, so that the shear forces are reduced by about $20 \%$ in the case of Arges Church compared to that of Cozia. The shearing force is inversely proportional to the distance from the center $\mathrm{CR}$ and the extreme points of the plane.

Next, in Fig. 10 is presenting a series of churches for which the shape of the three-lobed plan was tried, but although, they did not have the same effect as in the case of the Arges Monastery church, they are still functional today. 

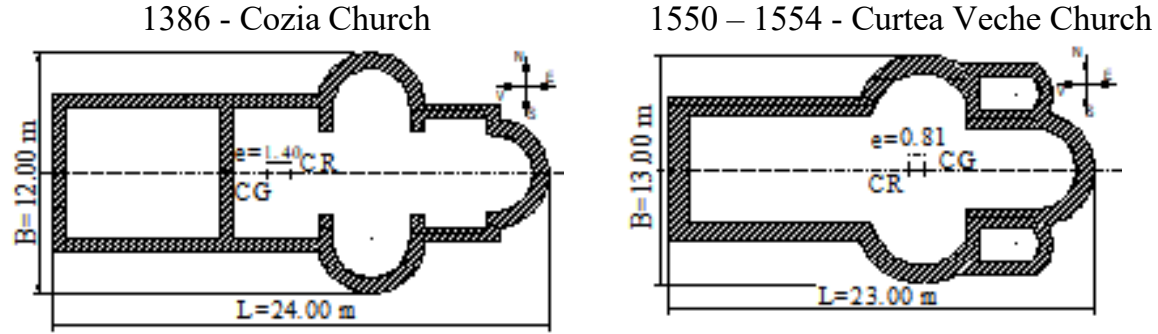

1512 - Arges Church

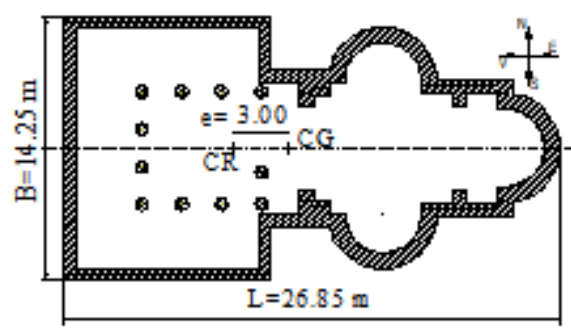

1580 - 1591- Mihai Voda Church

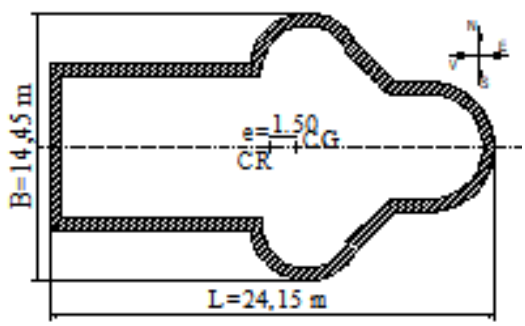

1517 - Snagov Church
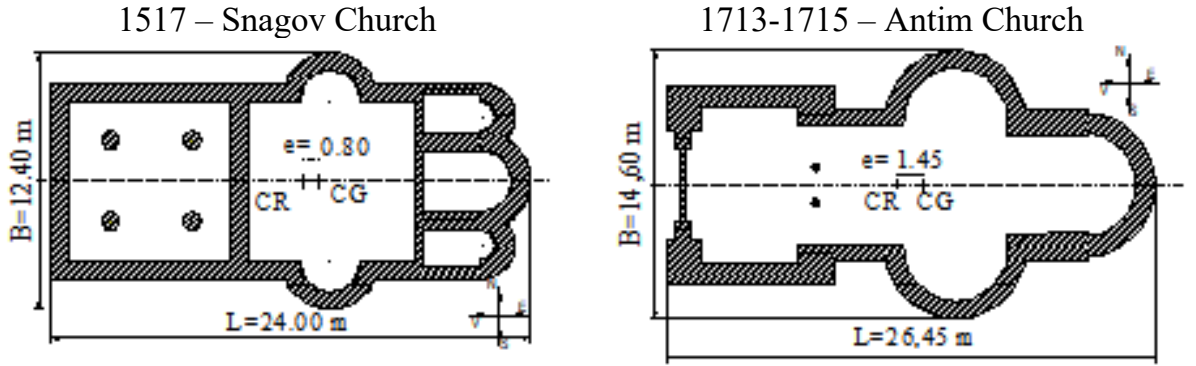

Fig. 10 - Seismic shaping of the three-lobed plan (expressed by CG and CR)

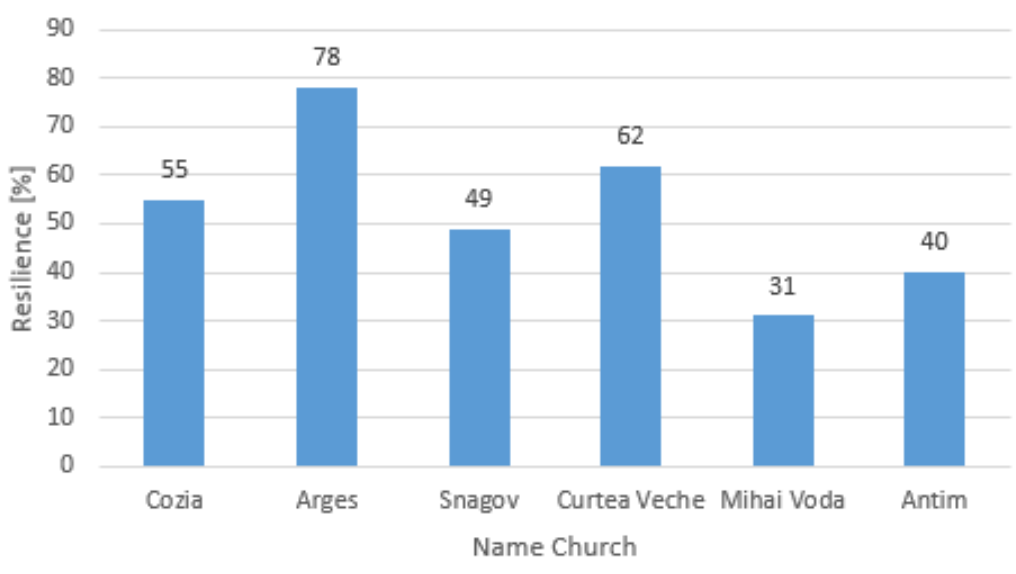

Fig. 11 - Seismic resilience of the three-lobed plan 


\subsection{The influence of the foundation depth on the behavior of the Arges Monastery Church}

Furthermore, to be able to establish the influence of the foundation on the behavior of the church, models were made in the Etabs program, taking into account the ground structure interaction.

Models were named as follows:

- Model 1 - low foundation depth, about $30 \mathrm{~cm}$;

- Model 2 - medium foundation depth, frost depth;

- Model 3 - foundation deeper than the frost depth.

The modification of the oscillation periods, depending on the foundation depth, are presented in the Fig. 12, 13 and 14.

Real model

Mode 1, T=1.448 s

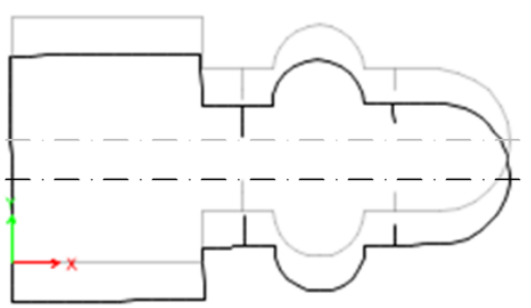

Mode 2, $\mathrm{T}=1.104 \mathrm{~s}$

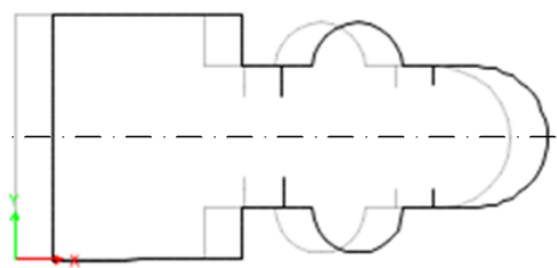

Mode 3, T=0.994 s

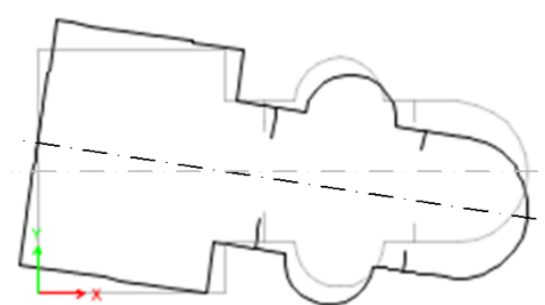

Three-lobed reference model Mode $1, \mathrm{~T}=1.369 \mathrm{~s}$

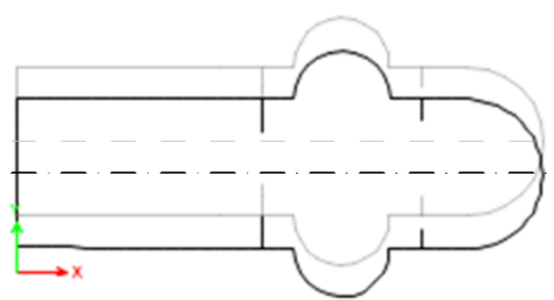

Mode 2, $\mathrm{T}=0.956 \mathrm{~s}$

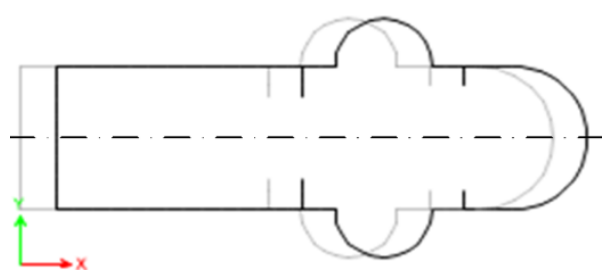

Mode 3, $\mathrm{T}=0.683 \mathrm{~s}$

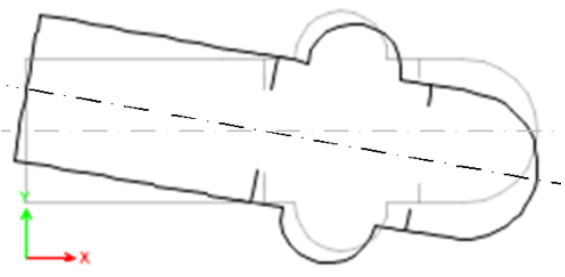

Fig. 12 - Distribution of oscillation modes - Arges Monastery Church for model 1 
Analyzing Fig. 12 it can be observed that when the structure has a shallow foundation, the periods of oscillation have increased substantially. In this situation, the passive resistance of the foundation ground is small, which makes the structure move freely on the ground. This phenomenon leads to the reduction of seismic forces and the protection of the church body. The same thing does not happen in the case of towers, where the effect of seismic jerk is consequently amplified.

Real model

Mode $1, \mathrm{~T}=1.104 \mathrm{~s}$

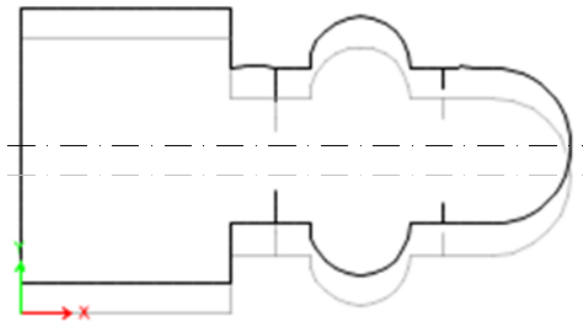

Mode 2, $\mathrm{T}=0.715 \mathrm{~s}$

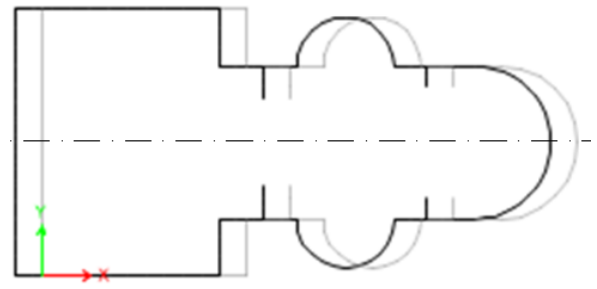

Mode 3, $\mathrm{T}=0.5 \mathrm{~s}$

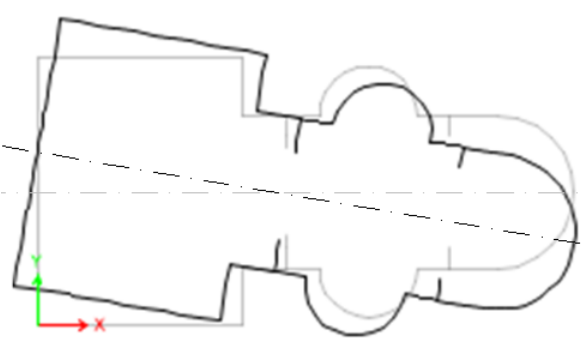

Three-lobed reference model

Mode $1, \mathrm{~T}=1.145 \mathrm{~s}$

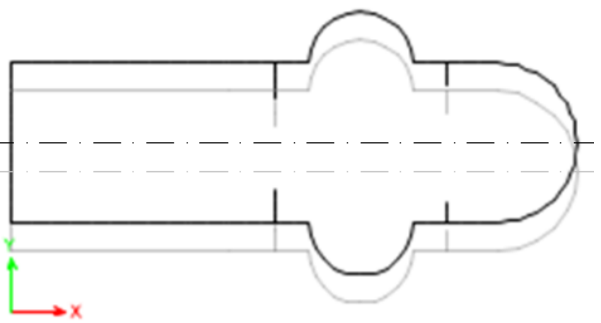

Mode 2, $\mathrm{T}=0.651 \mathrm{~s}$

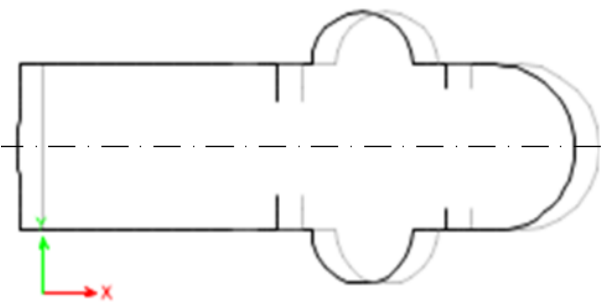

Mode 3, $\mathrm{T}=0.427 \mathrm{~s}$

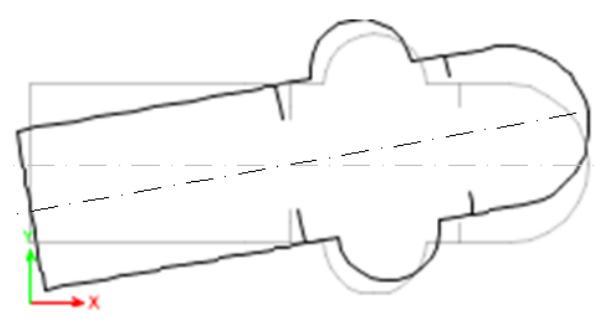

Fig. 13-Distribution of oscillation modes - Arges Monastery Church for model 2

From Fig. 13 and Fig. 14 one notice that with the increase of the foundation depth the period of the structure decreases. The decrease of the period leads to the increase of the basin shear force, but also reduction of the jerk effect. In this case, the effects of the earthquakes on the church are higher. 


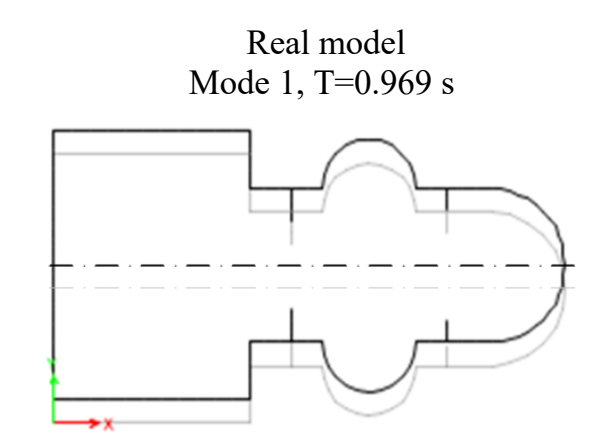

Mode 2, $\mathrm{T}=0.628 \mathrm{~s}$

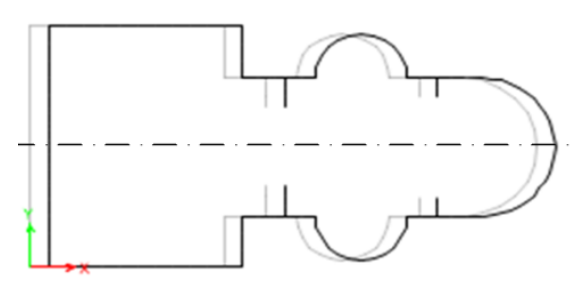

Mode 3, $\mathrm{T}=0.182 \mathrm{~s}$

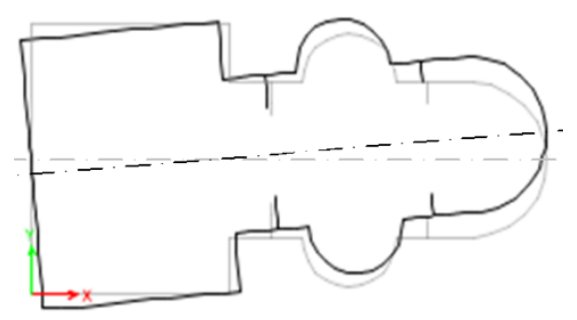

Three-lobed reference model Mode 1, T=1.174 s

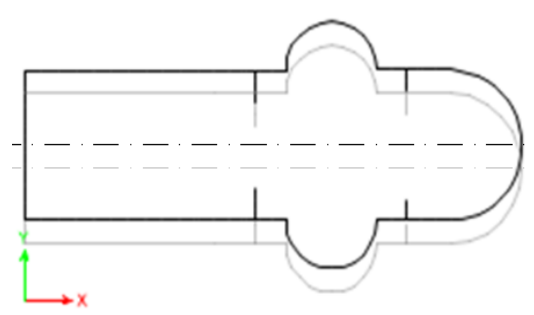

Mode 2, $\mathrm{T}=0.639 \mathrm{~s}$

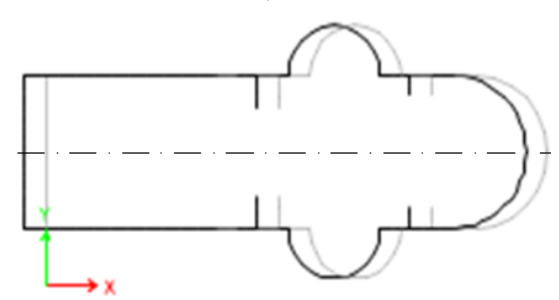

Mode 3, $\mathrm{T}=0.177 \mathrm{~s}$

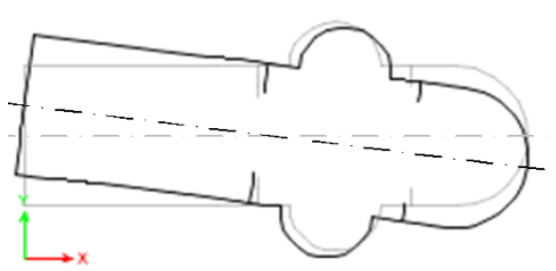

Fig. 14 - Distribution of oscillation modes - Arges Monastery Church for model 3

The depth of foundation must be chosen carefully so that the incidence of an earthquake will produce minimal degradation in all structural elements.

\subsection{Effect of the seismic jerk}

The effect of the seismic jerk was determined for the National Orthodox Cathedral in Bucharest, because it has a particularity, namely, the three-lobed plane does not reach the bottom of foundation. This church has the length of $\mathrm{L}=125.40 \mathrm{~m}$, the width of $\mathrm{B}=54.60 \mathrm{~m}$, height of $\mathrm{H}=112.50 \mathrm{~m}$. In the seismic response analysis, parameters of the church body were marked with 0 , and for the Pantokrator steeple with E. According to the special numerical model, $\mathrm{V}_{0}=188622 \mathrm{~m}^{3}$ and $\mathrm{V}_{\mathrm{E}}=30728 \mathrm{~m}^{3}$. Dynamic amplification factors $\psi=\mathrm{V}_{0} / \mathrm{V}_{\mathrm{E}}=6.138$. Given that the maximum ground velocity for the earthquake recorded in $1977, \mathrm{v}_{0}=0,71 \mathrm{~m} / \mathrm{s}$, calculate $\mathrm{v}_{\mathrm{E}}=0.71 \times 6.18=4.358 \mathrm{~m} / \mathrm{s}$. 


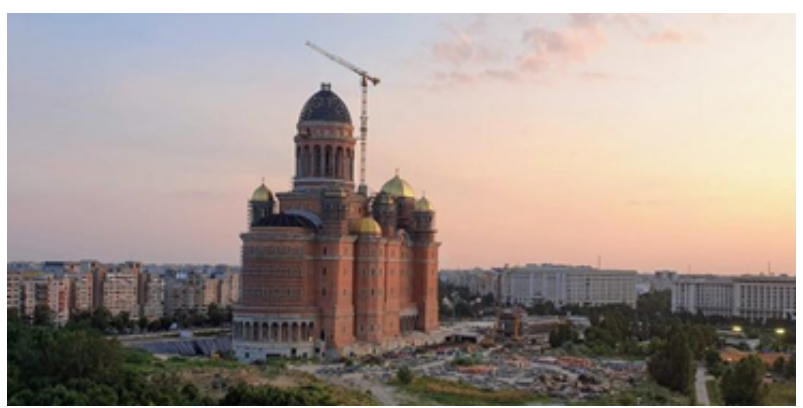

Fig. 15 - National Orthodox Cathedral

The mass of the Pantokrator steeple has a value of $m_{E}=75$, resulting in a force corresponding to the impulse for the Pantokrator steeple is $\mathrm{F}_{\mathrm{E}}=$ $750546 \times 4.358 / t=3.27 / t(M N)$. It is estimated that the Pantokrator steeple has a shear capacity of $\mathrm{F}_{\text {cap }} \approx 20 \mathrm{MN}$ (Sofronie, 2017).

\section{Conclusion}

Since the fourteen century, the three-lobed pattern was consecrated to the Eastern Churches. Unfortunately, during the earthquakes, the rounded walls of the three lobs were often, severely damaged. It was a matter of geometry before to be one of strength. The solution was discovered during the construction of the Arges Monastery Church, between 1512 and 1518, inspired by the myth of immolation, the pronaos was a little enlarged. By this reshaping, the centre of rotation has changed its relative position with the centre of gravity and moved from naos into pronaos. Since then, all churches similarly shaped became protected against earthquakes. In the paper, five old churches of Romanian Cultural Heritage were also comparatively analysed. Each church reached the level of seismic resilience in the accordance with its shape. However, the highest resilience remained that succeeded in 1512. The paper also investigated the influence of foundation depths on church seismic resilience. It was found that shallow foundations are dramatically reducing the seismic resilience of threelobed churches. The influence of the steeple dimensions expressed by the ratio between their height and diameter is also important. In the case of the steeples, seismic jerks often occur. There is an art to seismically proportionate the threelobed church.

Acknowledgments The author is expressing his respectful thanks to the distinguished Professor Ion Giurma, Ph.D., for his kind support to submit this paper to the Scientific Bulletin of the University Gheorghe Asachi in Iasi. The unconditional support of UNESCO Chair \#177 in Bucharest for carrying out his doctoral thesis, supervised by Emeritus Professor Ramiro Sofronie, Ph.D., D.H.C., and for helping preparing this original paper is also gratefully acknowledged. 


\section{REFERENCES}

Beles A., La notion de sécousse et son rôle dans le dynamique, Buletinul Societatii Politecnice, Bucuresti,1937.

Eliade M., Comentarii la Legenda Mesterului Manole, Publicom, Bucharest, 1943.

Ionescu G., Arhitectura pe teritoriul Romaniei de-a lungul veacurilor, Bucuresti, Editura Academiei Republicii Socialiste Romania, 1982.

Paun S., Romania. Valoarea arhitecturii autohtone, Per Omnes Artes, Bucharest, 2003.

Sofronie R., The Behaviour of Eastern Churches in Earthquake, 7th European Conference on Earthquake Engineering, Athens, Greece, (1982).

Sofronie R., Post-seismic Strengthening of Churches, IABSE Symposium, Venezia, (1983).

Sofronie R., On the seismic jerk, Journal of Geological Resource and Engineer, New York, 4:147-152, (2017).

Sofronie R., On the seismic resilience, Journal of Geological Resource and Engineer, New York, 7:132-139, (2019).

Sofronie R., Virsta A., Conservation of Three-Lobed Churches, Hong Kong, pp. 127133, (2006).

Stefanescu G., Cutremurele de pamant in Romania, Bucuresti, analele Academiei Romane, TOM XXIV - Memoriile sectiei stiintifice, 1901.

Timoshenko S. P., Strength of materials: Elementary Theory and Problems, Van Nostrand, Michigan Technological University, USA, 1930.

Timoshenko S. P., History of Strength of Materials, Dover, New York, USA, 1953.

\section{MODELAREA NUMERICĂ A TESTELOR PE ZIDĂRIE}

\section{(Rezumat)}

Articolul tratează bisericile trilobate, ca fiind cele mai reprezentative creații ale arhitecturii ecleziastice și monumentale conservate în zona carpato-dunăreană-pontică. Începând cu secolul al XIV-lea, în Moldova și Țara Românească, vechile biserici de lemn, deseori amenințate de foc, au fost înlocuite cu cele din zidărie de piatră sau cărămidă. Din păcate, cutremure puternice și persistente se produc în acea zonă. Zidăria din piatră sau cărămidă, cu mortar din lut sau var, folosită pentru bisericile trilobate, inclusiv la fundațiile și clopotnițele acestora, a fost adesea grav avariată de cutremure. Potrivit unei vechi legende, în cazul Bisericii Mănăstirii Arges, avariile se produceau în timpul nopților. Pentru a salva biserica, în virtutea unui mit vechi, Meșterul Manole și-a imolat soția într-unul dintre pereții pronaosului. $\mathrm{Cu}$ acea ocazie, întregul pronaos a fost reconformat, iar de atunci biserica nu a mai fost avariată. Cercetările ulterioare au arătat că prin reconformare, pozițiile centrelor de masă și de rotație au fost inversate. De atunci, acea biserică de la Curtea de Argeș, în timpul serviciului său îndelungat de 503 ani, a fost cruțată de cutremure de orice avarie. Același destin fericit l-au cunoscut toate bisericile trilobate construite ulterior cu pronaosul lărgit. 